\title{
Re-visiting the interrelatedness between spatiality and temporality in migration research
}

\author{
Nguyen Hong $\mathrm{Chi}^{{ }^{1 *}}$ \\ ${ }^{1}$ FPT University, Vietnam \\ *Corresponding author: chinh6@fe.edu.vn
}

\begin{tabular}{|c|c|}
\hline ARTICLE INFO & ABSTRACT \\
\hline $\begin{array}{l}\text { DOI: } 10.46223 / \mathrm{HCMCOUJS} \text {. } \\
\text { econ.en.9.2.159.2019 }\end{array}$ & $\begin{array}{l}\text { There have been a lot of debates over the relationality } \\
\text { between spatiality and temporality in extant migration research. In } \\
\text { terms of space, several strands of research have focused on } \\
\text { exploring migrants' strategies for migration and relocation, } \\
\text { implicitly considering migration as a complete sojourn. However, } \\
\text { migrants tend to establish and maintain transnational ties across } \\
\text { spaces, making migration an on-going process. Others have } \\
\text { examined how migrants sustain transnational activities and } \\
\text { relationships over time. Migration, in the latter sense, becomes a } \\
\text { complex process involving multiple times and spaces. Migrants' } \\
\text { mobilities are shaped and reshaped by their past memories, present } \\
\text { relocation experiences, and aspirations for the future, as well as }\end{array}$ \\
\hline Received: May $18^{\text {th }}, 2019$ & \\
\hline Revised: June $19^{\text {th }}, 2019$ & $\begin{array}{l}\text { spaces. This raises theoretical questions about how time is } \\
\text { embedded in space and what time and space mean to migrants. }\end{array}$ \\
\hline Accepted: August $15^{\text {th }}, 2019$ & $\begin{array}{l}\text { This paper argues that the core of the debates is grounded in the } \\
\text { ways migrants experience subjectivities in defining what their } \\
\text { mobilities mean to them. This argument is presented through a } \\
\text { literature analysis of key research on the interrelated issues of } \\
\text { temporality and spatiality, roots and routes, as well as assimilation } \\
\text { and dissimilation that partly contribute to the meanings of } \\
\text { mobilities. It offers an overview of current research on } \\
\text { transnationalism and advances the current debates on temporality } \\
\text { and spatiality. In this paper, temporality and spatiality in migration }\end{array}$ \\
\hline $\begin{array}{l}\text { Keywords: } \\
\text { assimilation, dissimilation, } \\
\text { migration, spatiality, } \\
\text { temporality }\end{array}$ & $\begin{array}{l}\text { are conceptualized as dynamic and intertwined entities, rather than } \\
\text { fixed or linear processes. This conceptualization is hoped to } \\
\text { clarify the ways in which researchers often become divergent in } \\
\text { their research strands, leaving gaps in understandings of current } \\
\text { migration schemes. }\end{array}$ \\
\hline
\end{tabular}

\section{Opening remarks about space and time}

Increasingly, international migration has become a global issue, with a large flow of people from 36 million in 1990 to 191 million in 2005 and 244 million in 2015 (United Nations [UN], 2016, p. 1). Within the global context of increasing migration, research begins to seek answers to paradoxical issues in migration such as agency and structure (e.g., Findlay 
\& Li, 1999; Silvey, 2004), brain drain or brain gain that incur among educated migrants (e.g., Gribble, 2008; Nguyen, 2006) or migrants' negotiations of cultural norms and political ideologies (e.g., Biao, 2007; Waters, 2006). One of the common debates is over the relationality between spatiality and temporality in migration research (e.g., Cresswell, 2006, 2010; Shubin, 2015; Yeoh, Leng, Vu, \& Yi'en, 2013). Essentially, migrants are depicted to maintain transnational activities with strong bonds to their home countries through knowledge transfer, philanthropic contributions and communication. They do not seem to live a detached life from home. The sustainment of transnational ties causes migration to be a dynamic process rather than a linear direction with a complete outcome. Migrants' transnationality is comprised of the places where they have been and the non-linearity of time involving their past, present, and future. This raises the question of how time is encountered in relation to space.

Such a question is, as the author argues in this paper, grounded in the arguments over how migrants experience subjectivity in defining what their migration means to them. Some may choose to do activities that make them easily adjust into host societies as routes, while others may try to sustain transnational networks to maintain their roots. Their engagements in transnational ties and/or attempts to adjust to host societies lead to assimilation and/or dissimilation. This is where a number of researchers explore migration as an on-going process from various angles. Some argue that migrants make sense of their continuous mobilities through strategies to overcome precariousness caused by conflicting ideologies in home and host societies (e.g., Robertson, 2014; Robertson \& Runganaikaloo, 2014; Yeoh et al., 2013). Others capture the meanings of mobilities through investigation into how migrants adapt to the workforce in destination countries (e.g., Chiswick \& Miller, 2006; Levey, 2008). Transnationalism researchers tend to look into migrants' transnational activities and use of objects to put forward these activities (e.g., Faist, 2000; Vertovec, 2009). These allow us to understand that transnational mobilities can comprise of migrants' negotiations of and strategies for migration, relocation and hopes for the future. Migrants' mobilities, in other words, can be constructed and reconstructed by their experiences in temporality and spatiality, roots and routes, as well as assimilation and dissimilation. In this sense, migration stretches beyond migrants' fixed arrival in destination countries to the sustainment of transnational activities across borders and times. In other words, the meanings of time and space matter to their migration experiences.

This paper summarizes key discussions in extant transnationalism research on the issues of temporality and spatiality, roots and routes, as well as assimilation and dissimilation as briefly outlined above. The purposes of this literature analysis are two-fold. First, it offers an overview of current research on transnationalism and further advances the debates on temporality and spatiality by adding that on-going migration processes involve migrants' negotiations of routes and roots through encounters with spaces, times and expectations to assimilate into and/or dissimilate from host societies. This paper goes beyond the notions of time as linearity and space as fixedness by arguing that these two notions are always intertwined and carry on intersubjective meanings, rather than objective senses. Second, this paper proposes three fundamental ways for researchers to explore the notion of home and belonging in 
migration, through the entwinements of time and space, assimilation and dissimilation, and roots and routes. These concepts are always interrelated in migrants' experiences. This paper adds nuance to some migration debates in current research (e.g., Cresswell, 2006, 2010; Shubin, 2015) in that it clarifies the ways in which researchers become divergent in their research strands, leaving gaps in understandings of current migration schemes.

It does so by firstly pointing out a plethora of discussions on temporality and spatiality in transnationalism studies. Some focus on outcomes of migration, considering migration as a complete journey as well as time and space as separate events and locales in migrants' lives. By taking a transnational perspective, others view migration as an on-going dynamic process and time and space as intertwined entities. Secondly, the next section of the paper analyses the interrelatedness of roots and routes as migrants sustain transnational activities and networks across times and spaces. As a result of negotiating roots and routes, migrants must attempt to adjust their relocation to some rules and social practices in host societies while giving up others to retain and nourish their roots. The last section of the paper deals with the issues of assimilation and dissimilation, sketching common themes in extant research on these two concepts and arguing that a better approach to unpacking these issues must look into migrants' everyday lives as well as macro-contextual factors such as multiculturalism, migration policies and the nexus between education and subsequent migration.

\section{Temporality and spatiality}

A rich body of work across geography, development studies, transnationalism and migration studies have focused on spatialities in several instances. For example, Hägerstrand's theory of time-geography (1975) considers time and space as resources and trade-offs for people's mobilities to achieve their everyday projects. This time-space path is subject to constraints of their everyday needs such as eating or sleeping, needs to be at some places at some time as someone else to achieve something, and needs to abide by laws that govern time and space of their activities. Nevertheless, Hägerstrand's approach seems to consider time as a simultaneity with space rather than speculating the former as the entwinement of people's lives. This approach has also been criticized for reducing mobilities to an abstract three-dimensional time-space diagram of life-path webs of individuals (King, 2012, p. 141). It strips potential differences and variations in mobility experiences. In contrast, our being is always an issue for us, despite the fact that we may express the same representation of mobilities and intentions for life-projects.

Recently, the time has been described through the sustainment of migrants' transnational relationships prior to and during relocation. Issues of time tend to be considered as simultaneity with relocation (Favell, 2007; Levitt \& Schiller, 2004), used to define typologies of migration (King, 2012), or taken as a methodological approach looking at durability of transnational relationships (Baas, 2007; King, Thomson, Fielding, \& Warnes, 2006; Waters \& Brooks, 2011). Extant research on highly skilled transnationalism has addressed micro-, mezzo- and macroperspectives with emphases on the importance of networks, contexts and local values, plus large scales of economic, political, cultural and legal structures (Gold, 1997). Most transnationalism studies consider migrants' relationships linked by an acquaintance, kinship and work relations, 
connecting migrants across space as units of analysis. Studies that take on board transnationalism perspectives have conceptualized temporality as lived time which manifests itself in migrants' experiences. However, there are some problems in theorizing temporality in these studies of this strand. According to Robertson (2014), time tends to be examined separately from space when the former is seen as a "subordinate element" to the latter (p. 1917). Time and space are then considered as objective domains in which migrants are said to respond to each of the separate events in their lives.

By focusing on migrants' responses to social structures and influences of others, some studies tend to conceptualize spatiality and temporality within the frame of agency and structure that exist within migrants' consciousness. For example, current transnational studies have often looked at the way migrants live their lives, which "incorporate daily activities, routines, and institutions located both in a destination country and transnationally [...] at the same time" (Levitt \& Schiller, 2004, p. 1003). In terms of methodological considerations of time in a longitudinal study over a period of 8 years, Waters and Brooks (2011) examined the durability of transnational relationships among migrants from Hong Kong and Taiwan to Canada. Their study has confirmed the persistence of transnational relationships over time and offered a methodological concern about the need for longitudinal quality of transnationalism. Similarly, by examining the temporal dimension of transnationalism, another research strand looks at migrants' assimilation or dispersion in host societies (e.g., Baas, 2007, 2010; Faist, 2000), and historical differences in the patterns and quality of transnational practices over time (e.g., Biao, 2007; Robertson, 2014). Time is seen as a space-dependent factor influencing migrants' mobilities. In other words, time is measured through distances, as if it were a dependent variable in relation to space.

The author of this paper argues that time and space are encountered both internally and externally from migrants' minds. Time and space involve migrants' interactions with multiple and heterogeneous actions shaped by their engagement with the world in various and potentially divergent directions in a wide spectrum of social fields. In addition, migrants' present engagement with the world and aspirations for the future are shaped by and through their interpretation of their past. Migrants' interactions with others and things are not simply fixed within a specific time or space. In fact, according to Cresswell (2006), movement is made up of time and space with the "spatialization of time and temporalization of space" (p. 4), and mobilities are not a "function" of time and space but an "agent" in the production of time and space (p. 6). Time and space are often seen as a conjunction of separate phenomena that may happen throughout migrants' lives (Collins \& Shubin, 2015). Mobilities are not simply movements from one place to another, but rather, strategies we use and meanings we embed in our movements make sense of mobilities. Migrants tend to experience time and space as "the geographical stretching-out of social relations" through their interactions with others (Massey, 1993, p. 60). In other words, it is our directedness towards a place and the meanings we assign for this directedness. In directing ourselves and being directed towards that place, we may arrive at the intended destination through the intended itinerary, change the routes and meanings, or even arrive at another destination as we find possibilities opening up in our routes. Our 
mobilities involve other people, materials, and infrastructure being placed under certain institutional regimes such as migration and visa policies, socio-economic and political conditions, family situations and communal practices. All of these regimes may enable and/or constrain our mobilities.

It is further posited that migrants experience space through their embeddedness in place with others and things over time. Space is experienced and embodied through migrants' involvement in the world which they share with others and things. For example, in a study of the Vietnamese diaspora in Australia and their gifts sent to their relatives in Vietnam in the late 1990s, Thomas (1999) reveals that these migrants use gifts to compensate their absence, fulfil their nostalgia, as well as expect to offer their relatives a sense of foreignness from Australia. In contrast, those who receive gifts express their disappointment, because they want to receive money instead of consumption products. Here, the contradiction in gift-giving and receiving shows that these migrants experience spatiality across Australia and Vietnam, from the past with memories about their relatives and hardship after the war to their present extension of familial relationships. They experience dislocations when knowing that their relatives are not happy to receive the gifts and later sell them for money. The space the Vietnamese diaspora experience involves their interactions with their relatives, material objects, past memories, as well as affections. Not only does space manifest itself in measurable distances, but it also is negotiated through migrants' interrelated interactions with others and things in a multiplicity of spaces and times. Space does not exist externally from migrants, but within their intersubjective-making of places with others and things.

\section{Roots and routes}

Migrants' fixities in host societies, which are associated with roots, may affect their further mobilities as negotiations of routes. Roots signify emotional bonds with the physical environment, shared culture and locality as local anchorage into place. Routes refer to ways that migrants are mobile yet attached to place as "culturally mediated experiences of dwelling and travelling" (Clifford, 1997, p. 5). While some argue that these two concepts are intertwined (Clifford, 1997; Gustafson, 2001), others acknowledge that cultural and ethnic attachment, as well as a sense of belonging, may distract migrants from making roots in host societies (e.g., Basch, Schiller, \& Blanc, 1994; Nagel, 2002,2009; Schiller \& Salazar, 2013; Smith, 2001). Current research on mobilities tends to unpack the inter-link between roots and routes as intertwined concepts. Yet, some studies on transnationalism acknowledge that the two concepts are not always complementary to each other. For example, cultural and ethnic attachment and a sense of belonging may distract migrants from making roots in host societies. Instead, the routes they are making are the sense of belonging to the home societies (Faist, 2000; Vertovec, 2009).

Sustained contacts and sustainment of transnational relationships are experienced as the routes they are making to maintain their roots.

These two notions are debated around the issue of belonging to place that migrant negotiate during their relocation and forming aspirations for future lives. As mentioned above, these studies have presented various findings on migrants' attachment to place, generally suggesting that place attachment and mobility as contradictory and/or complementary. In 
addition, most current studies on transnationalism have explored migrants' attachment to place through ethnic and cultural attachments, as well as transnational practices. This approach raises the question of how migrants experience time through their embeddedness in place. While transnational mobilities involve an extension of space from one place to another, migrants concurrently encounter intersecting influences of their duty, responsibility, and desire which are shaped by their past experiences and future projection (Yeoh et al., 2013).

In negotiating roots and routes in transnational social fields, migrants may have to face disparities, inequalities, religious and racial issues that facilitate and legitimise mobility and fixity (Schiller \& Salazar, 2013, p. 183). Smith (2001), for example, argues that transnational practices enabled by the governance of dual citizenship limit migrants from assimilating in host societies. Instead, some migrants may incorporate in the new society and concurrently maintain their roots with the countries of origin, whereas others do not participate in transnational activities at all. Integration in host societies and commitment to home countries are not necessarily exclusive but can be complementary (de Haas, 2010, p. 247). Sustained transnational contacts, relationships and practices are experienced as the routes they are making to maintain their roots which, in some cases, may not be necessarily grounded in receiving countries. The author of this paper agrees that migrants always negotiate roots and routes, making migration incomplete. They may even move unphysically after arriving in host societies. Therefore, one way to understand mobility is to explore migrants' negotiations of mobility which is affected by the immobility of others. It is suggested that we focus on dwelling mobility.

Dwelling mobility is seen as the emergent theme of research, or as Chaney (1979) noted on the flows of Caribbean peoples to the United States during the 1970s that there are now people who have their "feet in two societies" (p. 209). In other words, through dwelling- mobility, migrants experience interconnected space, in which distances are experienced only through their interactions with others and things over time. Their dwelling in the world with others and things across space and time makes transnational mobilities fluid and complex, rather than fixed and linear. This also means we must look at how migrants deal with assimilation and dissimilation issues that emerge during their relocation.

\section{Assimilation or dissimilation}

This section outlines the interrelatedness between assimilation and dissimilation in relation to space and time. Migrants' efforts to adjust in host societies and maintain transnational networks influence how they assimilate themselves and/or break up with some socio-cultural norms to make sense of their mobilities. Their strategies and tactics are always grounded in certain spaces and times. For example, Biao's (2007) work shows how information technology Indian professionals' skilled labor mobility is managed by cultural practices grounded in the home castes in India that influence their migration to the US and Australia. These influences shape their uses of dowries in their home communities at present, choices of IT programs in Western countries and migration prospects after future graduation. Their negotiations of this socio-cultural norm in India illustrate how they are embedded in the current time that shapes their decisions to migrate and expectations of future migration to Western 
countries. Such efforts are experienced through migrants' embeddedness in time and space with others as well as negotiations of routes and roots. This interrelation is implicitly shown in the past and the recent research that this section aims to analyze with regards to issues between personal belonging and multiculturalism policies, and international education and skilled migration under a transnationalism lens.

In the recent past, migrants were considered as permanent settlers who receiving states treated as assimilated subjects through immigration policies. However, since the 1970s, the growth of transnational networks and ethnic community formation has led to a more fluid multicultural approach to immigration schemes, allowing migrants to owe allegiance to more than one state (Castles, 2004, p. 863). Multiculturalism has facilitated ethnic pluralism but challenged social cohesion. A large body of research on Australian multiculturalism has examined its influence on politics, demography, cultural identity, transnationalism and labour market outcomes (e.g., Chiswick \& Miller, 2006; Levey, 2008; Vertovec, 2009). It is widely acknowledged that Australians supported the federal government in designing a multiculturalist platform for enabling migrants' adjustment into society after the White Australia Policy of Anglo-conformity was dismantled, but concurrently opposed policies that encouraged uses of ethnic languages and cultures (Chiswick \& Miller, 2006; Levey, 2008). Other studies (e.g., Bastian, 2012; Jupp, 2007) have reported historical changes in the governance of multiculturalism to support cultural pluralism, leading to services for ethnic language instruction and translation (with Vietnamese as one of the six most popular ethnic languages in Australia) and delivery of ethnic broadcasting services. In place of assimilation, the policy has focused on integration. For example, the recognition of overseas educationalcredentials has also been supported by Australian state/territory Overseas Qualifications Units (which was the former National Office for Overseas Skills Recognition). There are also a number of language courses provided by schools, colleges, universities and religious organizations to teach, enhance and support new migrants in terms of English language skills and translation. In Australia, multiculturalism has become an issue of social justice in nation-building, rather than a set of cultural policies that immigrants were required to follow (Jakubowicz \& Monani, 2010, p. 22). In general, Australia has encountered a "changing face" (Bastian, 2012, p. 55). It has been argued that uniformity in ethnicity and identity in the population does not generally serve the receiving society, as it requires new skills to face a changing global context in which the diversity of languages, cultures, and religions are viewed as productive forces.

Assimilation is not always an inevitable process of adjustment which can be measured through a list of indicators. Some research (e.g., Smith, 2001; Vertovec, 2009) juxtapose the relations between transnational and local levels in relations to migrants' place of origin that form an important part in their everyday lives. Smith (2001), for example, argues that by reaching out to diasporas, transnational practices of some countries in granting dual citizenship limit migrants in terms of assimilating to the host culture. Levitt and Jaworsky (2007, p. 131) also acknowledge that new assimilation theory has tended to consider by living transnationally, migrants can overcome poverty and enhance power to which capitalism relegates them. The dichotomy between transnational and local levels is not always mutually exclusive, as 
transnational ties may not prevent migrants from assimilation. A number of recent studies (e.g., Nagel, 2009; Schiller \& Salazar, 2013) have argued that migrants do not always lose their distinctiveness to become like the mainstream population in host societies. Assimilation theories are critiqued for assuming a sequential adaptation of migration in receiving societies by constructing middle- class society as the "norm to which migrants should aspire" (Nagel, 2009 , p. 400). These theories, therefore, are unable to interpret transnational lives that exceed national borders. Transnationalism literature tends not to challenge the ecological understanding of assimilation. Nagel (2009) has suggested that studies dealing with assimilation issues pay attention to the "ideological and political deliberations" taking place in both home and host societies that shape those who are in the "mainstream" and who remain "outside of [their] boundaries" (p. 401). By placing a focus on these deliberations, researchers can understand that assimilation is not only a "pattern of sameness", but as a "relational process of making sameness" (p. 401).

The growth of international students is both an effect of the changes introduced through multiculturalism and a contributor to changes in how multiculturalism is understood and practiced. Two-step migration contributes to further socio-political and cultural changes. For example, the education-migration nexus has raised questions about the human and citizenship rights of international students (Robertson, 2013; Robertson \& Runganaikaloo, 2014). In response to international students' demands for PR (permanent residency), some tertiary education providers became "PR factories" (Baas, 2014, p. 213) by designing cheap and lowquality vocational programs, prioritizing corporate profits ahead of their duty of care to international students. To deal with "migration corruption" (Robertson \& Runganaikaloo, 2014, p. 210), along with concerns about student welfare, and following the Baird Review (Baird, 2010), in 2011, the Australian Government, for instance, amended the Education Services for Overseas Students Legislation. This legislation amendment required education providers to demonstrate capacity in providing quality education, reducing risks posed to international students who took low-quality courses for a migration outcome, as well as enhancing the brand of the Australian higher education industry. Later, in response to the Knight Review in 2011, Department of Immigration and Border Protection (DIBP, 2013) has introduced other types of skilled visas giving priorities to PR applicants with state and employer sponsorship to strengthen the match between migration and labour market needs. Situating two-step migrants before and within this period, some research has explored the precariousness and fragile existence of their temporary status, labour exploitation, unemployment, as well as lostness and loneliness in Australia. These studies highlight scandals around the exploitation of student migrants, by coethnic entrepreneurs, and migration-related corruption in education prior to the considerable shifts of migration policies narrowing occupations in demands after 2007 and focusing on employer sponsorship since 2009 (e.g., Biao, 2011; Robertson, 2013; Robertson \& Runganaikaloo, 2014). The case of Australia shows that education-related migrants may have to negotiate their own circumstances with policy changes in receiving societies at all times. Their negotiations do not usually originate from either host or sending countries, but from their embeddedness in transnational spaces across times. 
According to Portes, Guarnizo, and Landolt (1999), transnationalism research forms a "highly fragmented" field without a "well-defined theoretical framework and analytical rigour" (p. 218). The issue is related to the requirement to take an interdisciplinary approach. Examining occasional transnational practices, indeed, does not shed much light on understanding transnationalism. It is pointed out that transnationalism research tends to examine cross-border activities and relationships as the rest of the population do once in a while with their known people and relatives overseas. This critique is similarly taken up by Itzigsohn, Cabral, Medina, and Vazquez (1999), who argue that investigations of migrants' occasional contacts are neither novel nor sufficiently distinct. Contacts with families and communities in home countries and establishing relationships with those in the same ethnicity in host societies have not been new. Instead, the high intensity of social exchanges, modes of transactions and multiplication of activities can contribute to understandings of how migrants' transnational relationships make sense on a regular and sustained basis. These researchers suggest that researchers delimit transnational practices into occupations and activities that require regular social contacts over time. They also critique the current tendency in transnationalism research to mix various units of analysis, creating confusion about what transnationalism actually refers to and what its scope of predication is. It is suggested that, by choosing individuals as a point of departure rather than starting with community or networks of social relations, researchers begin with the history and activities of migrants so that we can explore institutional underpinnings of transnationalism and its structural effects (Portes et al., 1999, p. 220).

In general, mobilities are "contingent" (Collins, 2008, p. 398) on the places where migrants move and the relationships they maintain across borders. It can be summarized here that migrants' assimilation and/or dissimilation is never anchored in a fixed place in a fixed point of time. Rather, it is manifest through migrants' encounters with socio-political norms and practices in relation to their personal, familial and communal contexts, as well as transnational activities they want to sustain. In this sense, research processes that focus on the issues of migrants' belonging should begin from their daily lives and respond to what Yeoh and Huang (2011) call for studies using "the lens of the everyday" (p. 688) of professional migrants who navigate their "professional, social and cultural life-worlds" (Beaverstock, 2011, p. 710) in relation to policy discourses. Doing this means researchers should probe into exploring the meanings of time and space that migrants experience.

\section{Concluding remarks}

Studies on transnationalism highlight the importance of social networks that shape and re-shape mobilities of skilled migrants through social links and shared relationships. In other words, these current studies in transnationalism have acknowledged migrants' engagement with the world across borders. By taking on board this perspective and analysing theintersections of migrants' involvement in the world, this paper conceptualizes migrants' lives as open and unfolding into a diversity of experiences, rather than being confined to a particular mode, place or time. In understanding the meanings embedded in practices of mobilities, this paper challenges the notion of place in people's movements, arguing that migration is not simply initiated and sustained by push or pull factors of places. Further, the notion of differences also 
enters the debate on mobilities, where people experience movements in different ways with different meanings, and some mobilities depend on the relative immobility of others. This paper acknowledges the importance of immobile entities such as national borders, place, law and policy regimes and even immobile people. Moorings are as important as mobilities.

This paper also shows that time and space are experienced through migrants' multiple and heterogeneous involvement with the world. An exploration of the entwinement of space and time responds to the need to develop a critical approach to understanding time and space as a conjunction of separate phenomena. It critiques the separation of time as past and present, and of space as place and placelessness. Instead, time and space are encountered as happenings and incompleteness of migrants' lives. Migrants keep projecting themselves into the future based on their experiences of living across the past and present in various social and geographical spaces. Their strategies for relation enable roots and routes to become dwelling mobility and blurring the fragile border between assimilation and dissimilation as well.

\section{References}

Baas, M. (2007). The language of migration: The education industry versus the migration industry. People and Place, 15(2), 49-60.

Baas, M. (2010). Imagined mobility - Migration and transnationalism among Indian students in Australia. London, UK: Anthem Press.

Baas, M. (2014). Victims or profiteers? Issues of migration, racism and violence among Indian students in Melbourne. Asia Pacific Viewpoint, 55(2), 212-225. doi:10.1111/apv.12046

Baird, B. (2010). Stronger, simpler, smarter ESOS; supporting international students: Final report, review of the education services for overseas students act 2000 (Final Report, Australian Government). Retrieved December 20, 2017, from https://internationaleducation.gov.au/Regulatory-Information/Education-Services-forOverseas-Students-ESOS-Legislative-Framework/ESOSReview/Documents/ESOS_REview_Final_Report_Feb_2010_pdf.pdf

Basch, L., Schiller, N. G., \& Blanc, C. S. (1994). Nations unbound: Transnational projects, postcolonial predicaments and deterritorialized nation-states. New York, NY: Gordon and Breach.

Bastian, B. (2012). Immigration, multiculturalism and the changing face of Australia. In D. Bretherton \& N. Balvin (Eds.), Peace psychology in Australia (pp. 55-70). New York, NY: Springer.

Beaverstock, J. V. (2011). Servicing British expatriate "talent" in Singapore: Exploring ordinary transnationalism and the role of the "expatriate" club. Journal of Ethnic and Migration Studies, 37(5), 709-728. doi:10.1080/1369183X.2011.559714

Biao, X. (2007). Global 'body shopping': An Indian labour system in the Information Technology industry. Princeton, NJ: Princeton University Press.

Biao, X. (2011). A ritual economy of "talent": China and overseas Chinese professionals. Journal of Ethnic and Migration Studies, 37(5), 821-838. 
doi:10.1080/1369183X.2011.559721

Castles, S. (2004). The factors that make and unmake migration policies. International Migration Review, 38(3), 852-884. doi:10.1111/j.1747-7379.2004.tb00222.x

Chaney, E. M. (1979). The world economy and contemporary migration. International Migration Review, 13(2), 204-212. doi:10.2307/2545027

Chiswick, B. R., \& Miller, P. W. (2006). Immigration to Australia during the 1990s: Institutional and labour market influences. In D. A. Cobb-Clark \& S-E. Khoo (Eds.), Public policy and immigrant settlement (pp. 3-24). Northampton, MA: Edward Elgar Publishing.

Clifford, J. (1997). Routes: Travel and translation in the later twentieth century. Cambridge, MA: Harvard University Press.

Collins, F. L. (2008). Bridges to learning: International student mobilities, education agencies and inter-personal networks. Global Networks, 8(4), 398-417. doi:0.1111/j.14710374.2008.00231.x

Collins, F. L., \& Shubin, S. (2015). Migrant times beyond the life course: The temporalities of foreign English teachers in South Korea. Geoforum, 62, 96-104. doi:10.1016/j.geoforum.2015.04.002

Cresswell, T. (2006). The right to mobility: The production of mobility in the courtroom. Antipode, 38(4), 735-754. doi:10.1111/j.1467-8330.2006.00474.x

Cresswell, T. (2010). Towards a politics of mobility. Environmental and Planning D: Society and Space, 28(1), 17-31. doi:10.1068/d11407

de Haas, H. (2010). Migration and development: A theoretical perspective. International Migration Review, 44(1), 227-264. doi:10.1111/j.1747-7379.2009.00804.x

Department of Immigration and Border Protection. (DIBP). (2013). Skilled occupations (Australia's Migration Trends 2013-14 Report of Australian Government). Retrieved December 10, 2017, from https://www.homeaffairs.gov.au/research-andstats/files/migration-trends13-14.pdf

Faist, T. (2000). Transnationalization in international migration: Implications for the study of citizenship and culture. Ethnic and Racial Studies, 23(2), 189-222. doi:10.1080/014198700329024

Favell, A. (2007). Rebooting migration theory - Interdisciplinary, globality, and postdisciplinary in migration studies. In C. B. Brettell \& J. F. Hollifield (Eds.), Migration theory: Talking across disciplines (pp. 259-278). New York, NY: Routledge.

Fielding, A. J. (1992). Migration and social mobility: South East England as an escalator region. Regional Studies, 26(1), 1-15. doi:10.1080/00343409212331346741

Findlay, A. M. (2002). From brain exchange to brain gain: Policy implications for the UK of recent trends in skilled migration from developing countries (International Migration Papers No. 43). Retrieved December 20, 2018, from International Labour Organization website: https://www.ilo.org/wcmsp5/groups/public/---ed_protect/---protrav/--migrant/documents/publication/wcms_201705.pdf 
Findlay, A. M., \& Li, F. L. N. (1999). Methodological issues in researching migration. The Professional Geographer, 51(1), 50-59. doi:10.1111/0033-0124.00144

Gold, S. J. (1997). Transnationalism and vocabularies of motive in international migration: The case of Israelis in the United States. Sociological Perspectives, 40(3), 409-427. doi: $10.2307 / 1389450$

Gribble, C. (2008). Policy options for managing international student migration: The sending country's perspective. Journal of Higher Education Policy and Management, 30(1), 2539. doi:10.1080/13600800701457830

Gustafson, P. (2001). Roots and routes: Exploring the relationship between place attachment and mobility. Environment and Behaviour, 33(5), 667-686. doi:10.1177/00139160121973188

Hägerstrand, T. (1975). Space, time and human conditions. In A. Karlqvist, L. Lunquist, \& F. Snickars (Eds.), Dynamic allocation of urban space (pp. 3-14). Lexington, MA: Saxon House Lexington Books.

Itzigsohn, J., Cabral, C. D., Medina, E. H., \& Vazquez, O. (1999). Mapping Dominican transnationalism: Narrow and broad transnational practices. Ethnic and Racial Studies, 22(2), 316-339. doi:10.1080/014198799329503

Jakubowicz, A., \& Monani, D. (2010). International student futures in Australia: A human rights perspective on moving forward to real action. Paper presented at Academy of the Social Sciences in Australia, Canberra.

Jupp, J. (2007). Australia: A changing identity. Australian Quarterly, 79(3), 66-70.

King, R. (2012). Geography and migration studies: Retrospect and prospect. Population, Space and Place, 18(2), 134-153. doi:10.1002/psp.685

King, R., Thomson, M., Fielding, T., \& Warnes, T. (2006). Time, generations and gender in migration and settlement. In R. Penninx, M. Berger, \& K. Kraal (Eds.), The dynamics of international migration and settlement in Europe (pp. 233-267). Amsterdam, Netherlands: Amsterdam University Press.

Levey, G. B. (2008). Multicultural political thought in Australian perspective. In G. B. Levey (Ed.), Political theory and Australian multiculturalism (pp. 1-26). New York, NY: Berghahn Books.

Levitt, P., \& Jaworsky, N. B. (2007). Transnational migration studies: Past developments and future trends. Annual Review of Sociology, 33(1), 129-156. doi:10.1146/annurev.soc.33.040406.131816

Levitt, P., \& Schiller, N. G. (2004). Conceptualizing simultaneity: A transnational social field perspective on society. International Migration Review, 38(3), 1002-1039. doi: $10.2307 / 27645424$

Massey, D. (1993). Power geometry and a progressive sense of place. In J. Bird, B. Curtis, T. Putnam, \& L. Tickner (Eds.), Mapping the futures: Local cultures, global change (pp. 59-69). New York, NY: Routledge. 
Nagel, C. R. (2002). Geopolitics by another name: Immigration and the politics of assimilation. Political Geography, 21(8), 971-987. doi:10.1016/S0962-6298(02)00087-2

Nagel, C. R. (2009). Rethinking geographies of assimilation. The Professional Geographer, 61(3), 400-407. doi:10.1080/00330120902941753

Nguyen, C. H. (2006). Brain drain or brain gain? The revitalization of a slow death. Essays in Education Online Journal, 16(3), 1-21.

Portes, A., Guarnizo, L. E., \& Landolt, P. (1999). The study of transnationalism: Pitfalls and promise of an emergent research field. Ethnic and Racial Studies, 22(2), 217-237. doi:10.1080/014198799329468

Robertson, S. (2013). Transnational student-migrants and the state. Basingstoke, Hampshire: Palgrave Macmillan.

Robertson, S. (2014). Time and temporary migration: The case of temporary graduate workers and working holiday makers in Australia. Journal of Ethnic and Migration Studies, 40(12), 1915- 1933. doi:10.1080/1369183X.2013.876896

Robertson, S., \& Runganaikaloo, A. (2014). Lives in limbo: Migration experiences in Australia's education - migration nexus. Ethnicities, 14(2), 208-226. doi: $10.1177 / 1468796813504552$

Schiller, N. G., \& Salazar, N. B. (2013). Regimes of mobility across the globe. Journal of Ethnic and Migration Studies, 39(2), 183-200. doi:10.1080/1369183X.2013.723253

Shubin, S. (2015). Migration timespaces: A Heideggerian approach to understanding the mobile being of Eastern Europeans in Scotland. Transactions of the Institute of British Geographers, 40(3), 350-361. doi:10.1111/tran.12078

Silvey, R. (2004). Power, difference and mobility: Feminist advances in migration studies. Progress in Human Geography, 28(4), 490-506. doi:10.1191/0309132504ph490oa

Smith, M. P. (2001). Transnational urbanism: Locating globalization. Oxford, UK: Blackwell.

Stark, O. (1991). The migration of labour. Oxford, UK: Basil Blackwell.

Thomas, M. (1999). Dislocations of desire: The transnational movement of gifts within the Vietnamese diaspora. Anthropological Forum: A Journal of Social Anthropology and Comparative Sociology, 9(2), 145-161. doi:10.1080/00664677.1999.9967504

United Nations (UN). (2016). International migration report 2015. New York, NY: United Nations. Retrieved December 22, 2018, from http://www.un.org/en/development/desa/population/migration/publications/migrationre port/docs/MigrationReport2015_Highlights.pdf

Vertovec, S. (2009). Transnationalism. New York, NY: Routledge.

Waters, J. L. (2006). Geographies of cultural capital: Education, international migration and family strategies between Hong Kong and Canada. Transactions of the Institute of British Geographers, 31(2), 179-192. doi:10.2307/3804380

Waters, J. L, \& Brooks, R. (2011). International/transnational spaces of education. Globalisation, Societies and Education, 9(2), 155-160. doi:10.1080/14767724.2011.576933 
Yeoh, B. S. A., \& Huang, S. (2011). Introduction: Fluidity and friction in talent migration. Journal of Ethnic and Migration Studies, 37(5), 681-690. doi:10.1080/1369183X.2011.559710

Yeoh, B. S. A., Leng, C. H., Vu, D. T. K., \& Yi'en, C. (2013). Between two families: The social meaning of remittances for Vietnamese marriage migrants in Singapore. Global Networks, 13(4), 441-458. doi:10.1111/glob.12032 